\title{
A New Book on Banking Four Hundred Years Ago
}

A book has recently been published in the field of medieval business which should be called to the attention of readers of the Bulletin. It is The Medici Bank: Its Organization, Management, Operations, and Decline, by Raymond de Roover. This hundred-page volume in large part appeared earlier in the form of articles in a learned journal, but it is now available to a wider circle of readers in attractive form and beautifully illustrated. This notice is especially addressed to businessmen, who presumably did not see the articles as they appeared in the Journal of Economic History. ${ }^{1}$

The author has an unusual combination of qualifications for writing in this field: experience in European business, advanced study in business and economics, work in business history under N. S. B. Gras, and a substantial foundation of research from original records in the history of medieval business.

It should be noted with emphasis that this is not a comprehensive study of the history of the business of the Medici-one cannot from it gain a complete picture of the business of that great and highly developed international house of sedentary merchants of late medieval Florence. As its title clearly indicates, this volume deals with the banking of the Medici in its organization, management, operations, and decline; and, as the author explains in his introduction, it is based on fragmentary survivals of the original records. The banking of this medieval concern could not be set forth without some reference to its larger interests, but the author has made everything else subordinate to his treatment of certain aspects of its banking. At the same time he has presented his material in the setting of the times; for example, in dealing with exchange transactions he takes the

\footnotetext{
'Published in July, 1948, by the New York University Press, this is a volume in the Business History Series of the Graduate School of Business Administration, New York University, edited by Professor Thomas C. Cochran. Its price is $\$ 4.00$.
} 
reader on a brief and very helpful excursion into the complicated mechanism of the medieval money market.

What has this book to offer that might be of interest to the businessman of today? First of all it gives a quick glimpse into one of history's richest and most creative business systems, that of Italy in the later medieval times. To be sure, the businessman of today would be somewhat confused to find himself back in that time, with its preIndustrial-Revolution manufacturing, its one-venture trading, its diversification, its system of partnerships, and its restricted investment opportunities. He would probably have a little difficulty in understanding the leading businessman of the times, the sedentary merchant. But he would soon find that he had much in common with this ancestor of his, and be quite at home in discussing with him such things as administrative problems and the difficulties of operating in a condition of falling prices and unsatisfactory investment opportunities. He would find much of interest, also, in examining with his medieval ancestor specific business organizations, techniques, and policies in particular circumstances. It is just this that Dr. de Roover makes possible, necessarily on a limited scale.

For example, the author shows how and with what success the Medici directed and controlled the managers of their distant branches. It is axiomatic in business that one must first of all choose good men. Cosimo, one of the great administrators of the Medici mercantile family, according to Professor de Roover did just that-but what of his successors? Then there is the problem of centralization versus decentralization - of a proper distribution of responsibility and power as between the head office and the branch, and the establishment of effective communication and controls. This aspect of the organization and operation of the Medici banking system is interestingly handled by the author.

The accounting controls were undoubtedly developed far beyond what those unfamiliar with that aspect of medieval business would have thought possible. An especially valuable part of this little volume is the reproduction in the appendix of many pages from private or firm account books. Those selections are made intelligible to us by the author's explanations.

Why do business concerns die? The author has no simple diagnosis of the fatal disease of the Medici partnerships, but he presents a complicated set of facts and circumstances. Certain external conditions were obviously important factors in the case, such as falling 
prices and difficulties that came from fundamental economic and business changes. But in the final analysis success or failure depends on the health of the business unit, which again depends to a large extent on the men who are responsible for its administration. Professor de Roover introduces the reader to interesting and diverse businessmen-on the one hand are Cosimo de' Medici and Angelo Tani and, on the other, Lorenzo de' Medici (The Magnificent) and Tomasso Portinari and Francesco Sassetti. These men are well worth an evening's reading. The businessman of today would find much in common with them, both in their problems and in the policies and techniques followed in meeting those problems.

Henrietta M. Larson

Business History Foundation, Inc. 